\title{
Dropout among Male Pupils in Primary Schools of Igembe District, Kenya
}

\author{
George M. Muthaa ${ }^{1 *}$, Misheck M. M’muyuri ${ }^{2}$, David Bururia ${ }^{1}$, Eric E. Mwenda ${ }^{1}$ \\ ${ }^{1}$ Department of Education, Chuka University, Chuka, Kenya \\ ${ }^{2}$ Burieruri Boys High School, Meru, Kenya \\ Email: *ericeliasmwenda@yahoo.com
}

Received November $12^{\text {th }}$, 2012; revised December $15^{\text {th }}$, 2012; accepted December $30^{\text {th }}$, 2012

\begin{abstract}
Education plays a key role in human development through the process of empowering people to improve their well being and participation in national building. Dropout however poses a serious threat to gains in education despite the Government emphasis on Education for All by the year 2015. In Igembe District the problem is more pronoused among the male children. The study used the ex-post facto research design. The target and accessible population constituted of educational officers, head teachers, guidance and counseling teachers and pupils. A sample size of 364 was used for the study. This study sought information on causes of dropout among boys and strategies that could be adopted to address this problem. The study established that dropout of male pupils was a common problem that required urgent attention. The major factors leading to dropout included; child labour, family instability, initiation, drug abuse and lack of role models. The study recommends affirmative action for the boy child, abolishing of child labour and initiation of boys after completion of primary school as strategies that could address dropout among male pupils.
\end{abstract}

Keywords: Dropouts; Male Pupils

\section{Introduction}

Education is the foundation of economic development of human resources without which limitations are bound to be there (Kichakuri, 2002). Psacharopoulos (1985) in his study on education for development found that education brought in high social rates of return which he estimated to be $27 \%$ for completed primary education and $15 \%$ - $17 \%$ for secondary education. Psacharopoulos (1985) also found that private returns of education were significantly higher than social returns reaching $49 \%$ for primary and $26 \%$ for secondary education. Psacharopoulos (1985) concluded that education remains a profitable occupation and its social rate of return exceeds. This gave impetus to the current study.

Todaro (1994) observes that causes of wastage vary from region to region, country to country, school to school and individual to individual. The World Bank (1998) called for various studies on dropout to be carried in various regions, countries and localities to minimize dropout and improve efficiency in education. The Media pointed out that due to the emphasis on "rerouting girls back to school", the dropout rate of girls had declined although it was still high in some districts such as Kisumu and Suba. Currently the dropout rate in the whole nation stands at $2.1 \%$ for boys and $2.0 \%$ for girls. Despite these observations no study had been done to establish the causes of higher dropout of boys. This gave impetus to the current study. The same report points out that in fighting dropout for girls the dropout of boys should also be considered because it can compound the problem. This was because the studies done at Suba District indicated that young men who dropped out of school enticed young girls with

"Corresponding author. money earned from fishing and made them to also drop from school (Mwaniki, 2008). The study sought ways of reducing boys' dropout which could also help in reducing girls' dropout.

In Igembe District, Kimondo (2007) observed that the dropout rate of male pupils in primary schools was higher than that of the females. Kimondo (2007) stated that from pre-school to standard four, there was a balance between the two sexes but later the number of males became very few. However he did not explain what caused that situation and that issue became the contention of this study. Gatere (2007) stated that the male child was endangered due to mass dropout from school despite the FPE. Gatere (2007) sited two cases of primary schools visited in Mutuati division in which one class had 10 boys against 30 girls in standard eight. The other case had only 5 boys in a class of 35 pupils in standard eight. Despite these observations no study had been made by policy makers and educationist in the region alike to establish the basis of the problem.

\section{Statement of the Problem}

Basic education is a pre-requisite for attaining the Kenyan Vision 2030 in which the country is expected to be industrialized. The major drawback in attaining EFA and vision 2030 is the school dropout. Despite the huge expenditure by the Government in providing free primary education, a substantial amount of this expenditure is spent on those who drop out of school. This is wastage of the scarce national resources since the dropouts had not acquired the knowledge and skills expected of them. In Igembe District the report from Kimondo (2007) and Gatere (2007) on education pointed out that the 
dropout rate of male pupils was higher to that of females. Despite these observations there was no research which had been carried out on the causes of that trend. The study sought to determine the causes of dropout of male pupils in primary schools.

\section{Objectives of the Study}

The study was guided by the following objectives:

1) To determine the causes of dropout on primary school male pupils.

2) To determine strategies of reducing the dropout of male pupils.

\section{Methodology}

The study used the ex-post facto research design. This study was carried out in Igembe District of Eastern Province. The District was chosen since according to Kimondo (2007) and Gatere (2007) it was among few Districts in Kenya in which the dropout of male pupils was higher than that of the females. The target and accessible population constituted of educational officers, head teachers, guidance and counseling teachers and pupils. In the study, standard eight pupils were sampled purposely. According to Kathuri and Pals (1993) a population of 6762 requires a sample of 364 individuals. This was obtained from 30 primary schools which were sampled using simple random sampling. The researcher used 30 head teachers and 30 guidance and counseling teachers from the sampled schools for this study. 26 sampled primary schools provided 10 class eight pupils each and the other 4 primary schools provided 11 class eight pupils each and this made a total of 304 pupils. A sample size of 364 was used for the study.

The data for this research was collected using questionnaires and observation schedule. There were three sets of questionnaires, one for standard 8 pupils, the second for head teachers and the third for guidance and counseling teachers. During visits to sampled schools the researcher made observations on the situation in the sampled schools and locations and paid particular attention to distance to school, socio-economic activities in neighborhoods of the school and engagement of the boys outside the school in the sampled community. The purpose of making personal observation was to obtain additional and collaborative data which enhanced the data gathered through questionnaire. In testing the reliability of the instrument, the Spearman's Rank Order Correlation Coefficient (r) was used. The data acquired by the researcher was both quantitative and qualitative data and was analyzed using the Statistical Package for Social Sciences (SPSS) version 11.5. Descriptive statistics was used in analyzing data.

\section{Findings}

The study sought information on gender of both head teachers and guidance and counseling teachers. Majority (83.3\%) of the head teachers were males and $16.7 \%$ were females. Similarly majority (56.7\%) of guidance and counseling teachers were males and $43.3 \%$ were females. This indicates that females were under represented in both the headship and in guidance and counseling in schools

The study sought information on the administrative experience of head teachers. This refers to the number of years teachers had headed a school. The questionnaire contained items that sought information on administrative experiences of head teachers. The study established that $43.3 \%$ of head teachers had been in headship for 0 - 5 years, $36.7 \%$ had been in headship for 6 - 10 years, $13.3 \%$ had been in headship for 11 - 15 years and $6.7 \%$ had been in headship for over 20 years.

The questionnaire sought information on the experiences of the guidance and counseling teachers. Majority of guidance and counseling teachers (80\%) had experience of only 0 - 5 years whereas $16.7 \%$ of guidance and counseling teachers had experience of 6 - 10 years and only $3.3 \%$ of guidance and counseling teachers had experience of 11 - 15 years. This indicated that majority of guidance and counseling teachers are relatively young in this area.

The researcher sought information on the courses undertaken by the guidance and counseling teachers in guidance and counseling. Only $6.7 \%$ of the respondents had diploma course in guidance and counseling and $6.7 \%$ had certificate in guidance and counseling. $16.7 \%$ of respondents had attended workshop, $6.7 \%$ had attended seminars while $36.7 \%$ had only covered guidance and counseling as a unit in college. This shows that majority of guidance and counseling teachers in primary school in the area of study had not been equipped with relevant skills to perform their duties. This may offer some explanation on the causes of dropout of the boy child.

The researcher used 153 boys (50.3\%) and 151 Girls (49.7\%). The researcher sought information on the age of the pupil respondents. Majority of the pupils, $62.8 \%$ were in age of 14 - 15 years. $11.3 \%$ of respondents were in age of $12-13$ years, $22.7 \%$ were in age of $16-17$ years while $3.2 \%$ were in age of 18 - 19 years. This implies that majority of the pupils are above the primary school going age. This may account partially for the dropout rate.

\section{Causes of Dropout}

A section was included in pupils' questionnaire that sought information on whether pupils knew any male pupils from their school who had dropped out of school. In the study, 94.4\% pupils indicated that they knew male pupils who had dropped out of school and only $4.6 \%$ of the respondents said they did not know any male pupil who had dropped out. Majority said that boys dropped out after circumcision since they became rebellious in school. Such student demand share of parent's property and others drop out of school in order to inherit their father's property. Others dropped out of school in order to look for money from lucrative miraa business. Other reasons stated are: use of drugs, unstable families, laziness, peer pressure, lack of motivation, forced repetition, lack of guidance, indiscipline, lack of basic things like food and clothes.

The researcher sought information on the classes in which dropout took place. Majority of male pupils (37.2\%) dropped out of school in class $5-6$ while $14.8 \%$ dropped in class $3-4$ and $30.1 \%$ in class $7-8$ whereas $14.1 \%$ of pupils indicated that dropout was uniform at all levels. 3.0\% of pupils did not respond to that item. The researcher sought further information on what the dropouts did to earn a living. Majority (94.4\%) of the respondents indicated that the school dropouts were employed as casuals in miraa picking or did petty miraa trade whereas $22.4 \%$ of the dropouts were employed as house boys while $15.1 \%$ were employed to take care of cattle. $4.6 \%$ of the respondents said that some of dropouts earned their living through stealing. 


\section{Extent of Dropout}

The researcher sought information from head teachers and guidance and counseling teachers on the extent of dropout of male pupils in their stations. In the study, $13.3 \%$ of head teachers and $13.3 \%$ of guidance and counseling teachers indicated that the dropout of male pupils had affected their institution to a very great extent, while $53.3 \%$ of head teachers' respondents and $63.3 \%$ guidance and counseling teachers' respondents indicated that the dropout of male pupils had affected their institutions to a great extent. Only $6.7 \%$ of head teachers respondents had no opinion, while $23.3 \%$ of head teachers respondents and $20 \%$ of guidance and counseling teacher respondents said that dropout of male pupils had affected their institutions to a small extent whereas 3.3\% of both head teacher and guidance and counseling teacher respondents said that the dropout of male pupils had affected their institutions to a very small extent. These findings implied that the dropout of male pupils affected the sampled schools to a great extent hence the need to seek for solutions to curb that problem.

Factors that led to the dropout of pupils could be school related or out of school. School related factors included: the school administration and the indiscipline. The out of the school factors were those found outside the school. Those included parent's social economic and marital status, child labor, HIV/AIDS, and traditions of the community. The questionnaire for pupils contained a section to inquire whether the respondents had felt like dropping out of school and $15.8 \%$ of the respondents said they had felt like dropping out of school. The reasons which made them feel like dropping out of the school, respondents gave the following reasons as illustrated in Table 1.

\section{School Administration and Dropout of Male Pupils}

The questionnaires contained parts that sought information on the effect of school administration on dropout of male pupils in primary schools. The views and opinions of head teacher, guidance and counseling and standard 8 pupils on the items of the questionnaire dealing with this aspect were analyzed as shown in the Table 2.

\section{Discipline and Dropout of Male Pupils}

The questionnaires contained items that sought information on the effect of discipline on school dropout of male pupils. Causes of dropout related to discipline included: drug abuse, indiscipline, rebellion against school environment, punishment and desertion. The leading factor was drug abuse which was mentioned by $66.7 \%$ of head teachers, $76.7 \%$ of guidance and counseling teachers and $66.8 \%$ of pupils. It was noted that drug abuse was mentioned more by the guidance and counseling teachers than others. The second factor was indiscipline which was stated by $70 \%$ of head teachers, $63.3 \%$ of guidance and counseling teachers and $63.2 \%$ of pupil respondents. These finding were similar to findings of Michieka (1983) who noted that indiscipline was one of the main contributor of dropout in Kisii. The effect of punishment on dropout was mentioned by $46.7 \%$ of head teachers, $33.3 \%$ of guidance and counseling teachers and $51.6 \%$ of pupil respondents. Rebellion against school environment was mentioned by $43.5 \%$ of head teachers, $50.0 \%$ of guidance and counseling and $39.1 \%$ of the pupils while desertion was not mentioned by any of the head teachers but was mentioned by $46.7 \%$ of guidance and counseling

Table 1.

Reasons for feeling like dropping out of school.

\begin{tabular}{ccc}
\hline & Frequency (F) & Percentage (\%) \\
\hline $\begin{array}{c}\text { Lack of basic needs such as food } \\
\text { Enticement from classmates who } \\
\text { dropped out of school }\end{array}$ & 24 & 37.5 \\
$\quad \begin{array}{c}\text { Divorce of parents } \\
\text { Irresponsible parents/drunkard } \\
\text { parents }\end{array}$ & 7 & 21.9 \\
Lack of motivation from parents & 5 & 12.5 \\
Mistreatment by step mothers & 4 & 10.9 \\
Not doing well in exams & 2 & 7.8 \\
Totals & 64 & 100 \\
\hline
\end{tabular}

Table 2.

Administrative related causes of school dropout.

\begin{tabular}{|c|c|c|c|c|c|c|}
\hline \multirow{2}{*}{ Major cause } & \multicolumn{2}{|c|}{ Head teacher } & \multicolumn{2}{|c|}{ Guidance and counseling teacher } & \multicolumn{2}{|c|}{ Standard 8 pupils } \\
\hline & $\mathrm{F}$ & $\%$ & $\mathrm{~F}$ & $\%$ & $\mathrm{~F}$ & $\%$ \\
\hline Lack of interest in enhancing activities & 18 & 60.0 & 15 & 50.0 & 106 & 34.9 \\
\hline Lack of motivation & 14 & 46.7 & 13 & 43.3 & 134 & 44.1 \\
\hline Lack of counseling & 12 & 40.0 & 8 & 26.7 & 140 & 46.1 \\
\hline Poor relationship between administration and pupils & 11 & 36.6 & 1 & 3.3 & 63 & 20.1 \\
\hline Poor academic performance & 10 & 33.3 & 16 & 53.3 & 160 & 52.6 \\
\hline Lack and conducive environment & 9 & 30.0 & 2 & 6.7 & 85 & 27.0 \\
\hline Poor relationship between head teacher and teacher & 2 & 6.7 & 1 & 3.3 & 48 & 15.8 \\
\hline Lack of confidence with head teacher & 2 & 6.7 & 0 & 0 & 27 & 8.9 \\
\hline Absenteeism of head teacher & 0 & 0 & 0 & 0 & 31 & 10.2 \\
\hline
\end{tabular}


teachers and $41.1 \%$ of the pupils.

The questionnaires sought information from respondents concerning the effect of parent socio-economic factors on dropout. The major factor which contributed to dropout included: Lack of role models which was mentioned by $73.3 \%$ of head teachers, $76.7 \%$ of guidance and counseling teachers and $47.0 \%$ of pupils. The second was low level of parental education which was stated by $66.7 \%$ of head teachers, $90 \%$ of guidance and counseling teachers and $53.9 \%$ of pupils. This was followed by hunger which was stated by $66.7 \%$ of head teachers, $76.7 \%$ of guidance and counseling teachers and $63.8 \%$ of pupils. The effect of lack of uniform to dropout was mentioned by $40 \%$ of head teachers, $46.7 \%$ of Guidance and counseling and $42.4 \%$ of pupils and that was found to be minor since it scored below $50 \%$ in the three questionnaires.

The researcher sought information on the effect of child labour on the dropout of male pupils in primary schools. Majority of Respondents; with (90\%) of head teachers, $96.7 \%$ of guidance and counseling teachers, and $89.8 \%$ of pupils indicated that child labour contributed to dropout. The effect of boys taking parental roles was low since it was only mentioned by $40 \%$ of head teachers, $50.0 \%$ of guidance and counseling teachers and $50.3 \%$ of pupils. $94.4 \%$ of the dropouts were either picking miraa or doing petty trade involving miraa. The observation schedule added more weight on that point since most of boys of school age seen around schools catchment areas were picking miraa, preparing and packaging miraa, carrying miraa from farms to towns and doing petty trade in miraa.

\section{Traditions and Dropout of Male Pupils}

The questionnaires contained sections that sought information on the effect of traditions on the dropout of male pupils in primary schools. The effects of traditions and initiations on dropout in the study was significant since was mentioned by $76.7 \%$ of head teachers, $83.3 \%$ of guidance and counseling teachers, and $57.9 \%$ of pupils. The respondents explained that after initiation boys are said to be grown up and have freedom to engage in activities of their choice. These traditional graduates assume that they have power and authority and when they go to school, they become rebellious and subsequently drop out of school. These traditional graduates are also entitled to inherit property of their parents, therefore most drop out of school to acquire properties.

\section{Sex Mainly Affected by Dropout}

The questionnaires sought information on the sex that was mainly affected by dropout. Majority (93\%) of head teacher felt that it was boys who drop out of school more than girls, while $87 \%$ of Guidance and Counseling teachers agreed with the head teachers and $54.3 \%$ of pupils said that boys were mainly affected by dropout than girls. That indicated that boys were more affected by dropout than girls in the district.

The researcher sought further explanation on why boys were dropping out of school more than the girls. The Head teacher said that boys drop out to pick miraa an activity which does not favor girls since it was a taboo for girls to climb trees. The other reason given was that initiation led for demand for more freedom and that caused rebellion and subsequent dropout from school. Traditional graduates were also entitled to inheritance of father's property and that led to lack of concentration in school and subsequent dropout from school. Contrary the girls were not entitled to inherit parents' property and the only way available for them to make up in life was to remain in school. Guidance and counseling teachers emphasized further that there was no proper follow-up of boys after initiation since they were said to be traditional graduates. The standard 8 pupils also emphasized that the money from miraa lured boys out of school especially from orphaned and unstable families due to many unmet needs.

An item was includes in questionnaires that sought information on whether the dropout of boys had any effect to the girls. Majority of head teachers (73.3\%) said that the dropout of boys also affected girls. That was supported by $60 \%$ of guidance and counseling teachers and $62.8 \%$ of the pupils. When the respondents were requested to give explanation for their answers, head teachers stated that the dropout of boys also affects girl since boys who dropped out of school acquired money from miraa which they used to lure girls leading to dropout. Guidance and counseling emphasized that the boys who had dropped out of school enticed girls in primary schools with money earned from miraa and that led to early sex which led to pregnancy. The pupils urged that the dropout acquired a lot of money from miraa which they used to buy presents to girls like mobile phones in exchange for sex which led to pregnancy and dropout. Others reported that: Due to lack of basis needs, some girls opt to borrow from classmates who dropped out of school and when this happens boys are rewarded with sex which led to pregnancy and subsequent dropout.

\section{Suggestions on Ways of Reducing the Dropout of Male Pupils}

The head teachers, guidance and counseling and standard 8 pupils were asked to give suggestions on what could be done to reduce the dropout of male pupils in primary school. The suggestions by the three sets of respondents are presented on Table 3.

Table 3.

Methods of addressing the problem of dropout in schools.

\begin{tabular}{|c|c|c|c|c|c|c|}
\hline \multirow[t]{2}{*}{$\begin{array}{c}\text { Method of addressing problem } \\
\text { of dropout }\end{array}$} & \multicolumn{2}{|c|}{$\begin{array}{l}\text { Head } \\
\text { teachers }\end{array}$} & \multicolumn{2}{|c|}{$\begin{array}{c}\text { Guidance and } \\
\text { counseling } \\
\text { teacher }\end{array}$} & \multicolumn{2}{|c|}{$\begin{array}{c}\text { Standard } 8 \\
\text { pupils }\end{array}$} \\
\hline & $\mathrm{F}$ & $\%$ & $\mathrm{~F}$ & $\%$ & $\mathrm{~F}$ & $\%$ \\
\hline S & 24 & 80 & 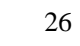 & 86.7 & 224 & 73 \\
\hline Forcing parents & 25 & 83.3 & 22 & 73.3 & 217 & 71 \\
\hline $\begin{array}{l}\text { Initiating bo } \\
\mathrm{sc}\end{array}$ & 21 & 70 & 23 & 76.7 & 229 & 75 \\
\hline $\begin{array}{r}\text { Strengthen } \\
\text { co }\end{array}$ & 21 & & ) & 5.7 & 227 & 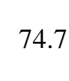 \\
\hline $\begin{array}{r}\text { Improvement } \\
\mathrm{scl}\end{array}$ & 20 & 6 & 18 & 60 & 169 & 55 \\
\hline Involvement of all & 17 & 56.7 & 14 & 46.7 & 125 & 41 \\
\hline Affirr & 16 & 53 & 15 & 50 & 145 & 47 \\
\hline Having activ & 14 & 46.7 & 15 & 50 & 142 & 46 \\
\hline $\begin{array}{c}\text { Abolish drugs such a } \\
\text { school }\end{array}$ & 12 & 40 & 10 & 33.3 & 129 & 42 \\
\hline Follow up of dropouts & 12 & 40 & 11 & 36.7 & 111 & 36. \\
\hline
\end{tabular}




\section{Conclusion}

The study established that dropout of male pupils in primary schools was a major challenge that requires to be addressed to urgently. The findings of the study indicate that there are shortcomings in the methods used by primary schools in curbing the dropout of male pupils. The guidance and counseling teachers have not been equipped with the relevant skills required to deal with the problem of dropout in schools. There is need therefore to take them for induction courses in order to equip them with necessary.

The study established the major factors that lead to dropout which includes: child labor, family instability, initiation and traditions, low level of parental education, drug and substance abuses, hunger and lack of role models. In order to overcome these problems, the study calls for joint effort among school administration, parents, sponsors, NGOs and other stakeholder in implementation of the suggested methods of curbing dropout of male pupils. The study established that there is a relationship between dropout of boys and that of girls since when boys drop out of school; they make girls also to follow the same suit.

\section{Recommendations of the Study}

Based on the findings of the current study, the following recommendations were made:

1) There should be affirmative action for boy child in the District. This is because education offers the best opportunity for one to come out of poverty and to be good managers of the resources available.

2) Community mobilization programmes are essential to sensitize people on the importance of education. This should be carried out through seminars and workshops.

3) Child labour should be discouraged and those involved prosecuted. The Provincial Administration should be vigilant arrest members of the community who hire school children to work in their miraa farms.

4) BOY's initiations should not be done to boys after completing primary school to improve the transition from primary to secondary.

\section{REFERENCES}

Abagi, O., \& Ondipo, G. (1997). Efficiency of primary education in Kenya: Situation analysis and implications for education reform. Nairobi: PAR Publication.

Akeyo, Q. M. (2004). Determination of drop out among students from secondary school in Homa-Bay District. Nairobi: University of Nairobi.

Gachoki, T. N. (2005). An investigation into the causes of drop out among male students in secondary schools in Kipiriri division of Nyandarua District. Nairobi: University of Nairobi.

Gatere, A. (2007). No schooling please, we are Igembe boys. Teachers' Image, a Quartely Magazine by the TSC, 14, 34-35.

Republic of Kenya (2002). Kenya gazette suplement, acts 2000. Nairobi: Government Printer.

Republic of Kenya (2003). Free primary education. A task force on its implementation. Nairobi: Government Printer.

Republic of Kenya (2003). Economic recovery strategy for wealth and employment creation. Nairobi: Government Printer.

Kathuri, N. J., \& Pals, E. (1993). Introduction to education research. Njoro: Egerton University.

Kichakuri, M. N. (2002). A study of wastage in primary schools of Taita Taveta District, Kenya. Kenya: Nairobi University.

Kimondo, C. (2007). Girls beat boys in attendance. Teachers' Image, a Quarterly Magazine by the TSC, 14, 31.

Mwaniki, M. (7 May 2008). Pregnancies kick girls out of school. The Daily Nation, 5.

Nafula, N. N. (2002). Achieving sustainable universal primary education through debt relief. Nairobi: KIPRA.

NARC (2002). NARC Manifesto: Democracy and Employment. Nairobi: NARC.

Psacharopoulos, G., \& Woodhall, M. (1985). Education for development, an analysis of invest and choices. Washington, DC: Oxford University Press.

Todaro, P. M. (1994). Economic development (5th ed.). New York: Longman Publishers.

Wangui, B. (10 September 2008). Alarms over boys dropout in central province. The East African Standard, 13.

World Bank (2003). Achieving UPE by 2015. A chance for every child. Washington, DC: International Bank for Reconstruction and World Bank Publication. 